\title{
INTRODUCTION TO IBERIAN GROUNDWATER AMPHIPODS
}

\author{
J. Notenboom \\ Institute of Taxonomic Zoology, University of Amsterdam, Post Box 4766, 1009 AT Amsterdam (Present adress: \\ National Institute for Public Health and Environmental Protection Post Box 1, NL-3720 BA Bilthoven, The Net-
} herlands).

Keywords: Iberia, Ground water, Amphipoda, zoogeography

\begin{abstract}
Zoogeographical data on Iberian ground water dwelling amphipods are given. The geographical ranges, habitats, and co-occurrences of the genera, are discussed. The Iberian peninsula is divided into zoogeographical districts based on these amphipods; some are correlated with geological units.
\end{abstract}

\section{INTRODUCTION}

Intensive sampling in continental Spain during the period 1983-1986 revealed many data about composition and distribution of ground water inhabiting fauna (stygofauna), especially crustaceans. This paper will deal with the amphipods of this fauna mainly on the generic level. Data about other groups of crustaceans collected simultaneously have been published by HENRY \& MAG. NIEZ (1987, 1988), CAMacho (1987), and Pesce \& Galassi (1988). A survey of localities sampled during our own investigation and on which most of the information provided in this paper is based is given in fig. 1 .

First, a review is given of what has been published before 1983 about Iberian ground water dwelling amphipods. Rather few authors paid attention to this fauna and their findings were based on very scattered data. A first treatise on crustaceans from Iberian continental waters was published by MARGALEF (1953). It included the subterranean fauna as well and served as the starting point of this review. Stygobiont amphipods recorded by Margalef (op. cit.) are: Pseudoniphargus (as $\boldsymbol{P}$. africanus Chevreux, 1901, from cave waters in the

Limnetica, 6: 165-176 (1990)

(C) Asociación Española de Limnología, Madrid, Spain
Cantabrian Mountains), Metacrangonyx (from the Balearic islands only), and Niphargus ( $N$. ciliatus cismontanus Margalef, 1952, from Guipuzcoa).

GiNET published a short paper in 1977, including data from Portugal as well (reproduced in Spanish in 1980), in which he stressed the scarce knowledge about the distribution in Spain of the genera Niphargus, Haploginglymus, Pseudoniphargus and Crangonyx. However, he did not mention the genera Bogidiella, Salentinella, and Hadzia. RuFFO (1953) already reported an unnamed representative of Bogidiella near Sitges (S of Barcelona), while B. hellenae was described by Mateus \& DE LOURDES MACIEL (1967) from the mouth of the river Douro (Portugal). The genus Salentinella was recorded for the first time by MARGALEF (1970a) from a cave near Alcoy (Alicante). In the same paper Margalef mentioned the presence of Pseudoniphargus in southern Spain, in the central Pyrenees and in the Catalan hills. Other records of Pseudoniphargus in northern Spain were given by Ortiz (1968), Villota \& Galan (1970), MarGalef (1970b), Gomarin Guirado (1978), and EsCOLA (1980).

In 1972, Mateus \& MAteus described Hadzia tavaresi from wells near the southern Portuguese coast (Algarve); STOck (1977) established a new genus, Metahadzia, for this species and also men- 
tioned some new localities. Mateus \& Mateus (1978) provided up to date distributions of the genera Bogidiella, Haploginglymus, Pseudoniphargus and Metahadzia in Portugal. In 1980a STOCK described a second species of Haploginglymus from a hyporheic habitat in the Cantabrian Mountains (northern Spain) and published in the same year a revision of the genus Pseudoniphargus, in which five new species were recognized from the Iberian peninsula. In his revision STOCK (1980b), also incorporated new material from northern and southern Spain. Recently, KARAman (1986a,b) reported on Niphargus and Haploginglymus based on the study of the older collections of Ginet and of Mateus, and established the existence of a third Haploginglymus species in central Iberia. A fourth form of Haploginglymus coexisting with Niphargus was recently discovered a spring south of the Catalan Pyrenees (Pretus \& SABATER, in press.).

The area around Madrid has been investigated during the last years by colleagues of the Museo
Nacional de Ciencias Naturales. Their material contained only Bogidiella (STOCK \& NotenBOOM, 1988). In this paper, bogidiellids from eastern and southern Spain are recorded as well. Our own investigations have been concentrated on the Cantabrian Mts. and the western part of the Pyrenees, the central-eastern part of Spain, and Andalusia (see fig. 1). In all areas visited it was attempted to sample a range of biotopes, such as the underflow of rivers, springs, wells, and cave waters. Data on the localities investigated in 1983 and 1984 have been published by NotenBoOM \& MEIJERS (1985). Additional sampling has been executed in summer 1985 by Peter van den Hurk and Remko Leys in the western part of Andalusia, and by Ine Meijers and Jos Notenboom in southern Valencia and the eastern part of Andalusia, and also in summer 1986 by Remko Leys and Katja Hogedoorn in Gallicia, and by Peter van den Hurk, Marc Koperdraat, and Jos Notenboom in Catalonia.

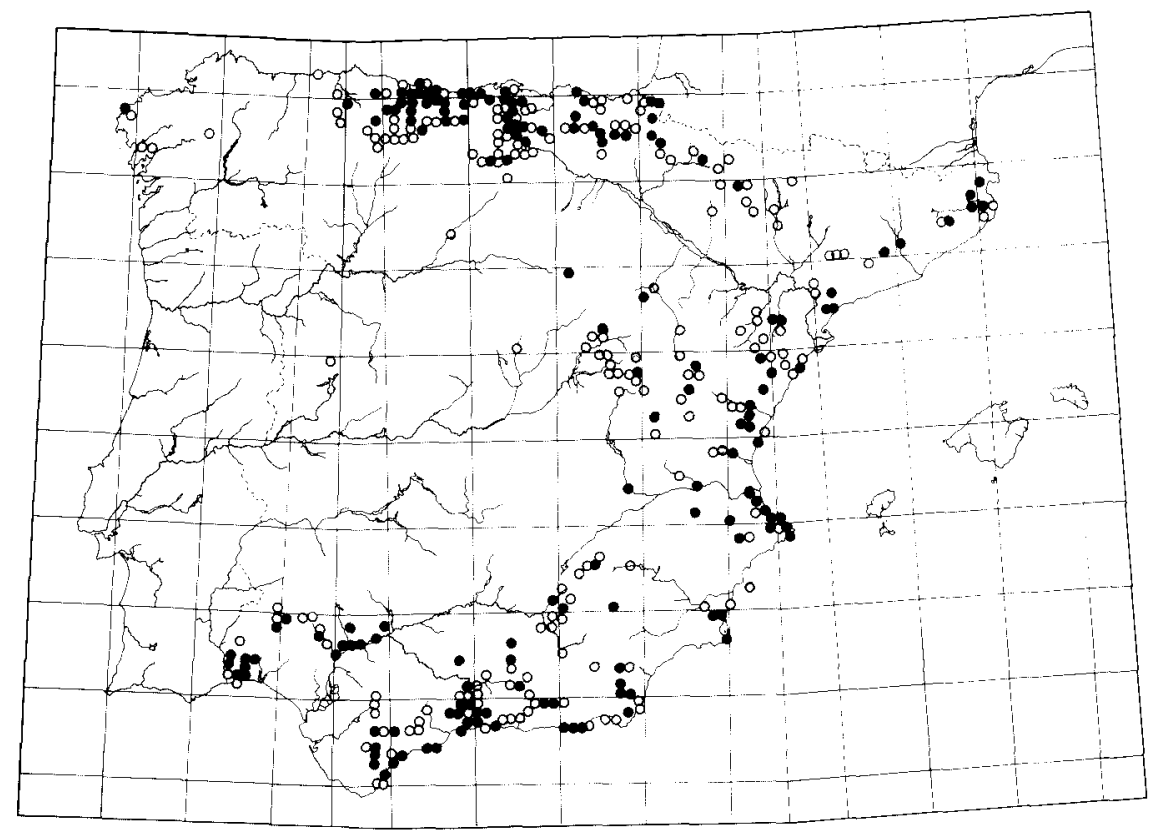

Figure 1.- Distribution of all groundwater samples taken during our campaigns of $1983-86$. Squares indicate $100 \times 100 \mathrm{~km}$ UTMgrid. Closed symbols indicate the situation of two or more samples taken within the same $10 \times 10 \mathrm{~km}$ UTM-square.

Distribución de las muestras de aguas subterráneas tomadas durante las campanas de muestreo realizadas entre 1983 y 1986 . La cuadrícula corresponde a las coordenadas UTM de $100 \times 100 \mathrm{~km}$. Los símbolos negros indican la situación de dos o más muestras tomadas dentro del mismo cuadrado de $10 \times 10 \mathrm{~km}$. 


\section{THE IBERIAN GROUNDWATER AMPHIPOD GENERA}

Niphargus Schiodte, 1849 (fig. 2)

This genus has an extended distribution; it stretches from western Europe into the Near East (KARAMAN \& RuFFo, 1986). In Spain it reaches its southwestern distribution limit and occurs in two segregated areas on both edges of the Pyrenean mountain ridge only. In the eastern Catalan Pyrenees the genus is mentioned by Ginet (1977) from La Mosquera cave near Beuda (prov. Gerona), identified by Karaman (1986b) as $N$. delamarei Ruffo, 1954. Our own investigations in Catalonia showed that Niphargus ranges from the Pyrenees into the province of Tarragona (about $150 \mathrm{~km}$ south of Pyrenees). In the area west of the Pyrenees (Basque Country and the northwestern part of the province of Burgos), the genus has been found frequently both in the past and during our own investigations. This is the classical Iberian
Niphargus region. Most likely the present distribution of Niphargus in Iberia is the result of dispersal from the area north of the Pyrenees, through the low altitude corridors west and east of the mountain ridge. This hypothesis is confirmed by the presence of trans-Pyrenean species, $\mathrm{N}$. delamarei in the east, and N. ciliatus and N. longicaudatus in the west (MARGALEF, 1952, 1970a,b; KARAMAN, 1986b).

Niphargus is a widely distributed stygobiont amphipod genus with a high species diversity, including species with large ranges. Supposedly, one of the reasons for its wide range is a rather high dispersa1 ability related with its capacity to colonize not only the phreatic level but also the unsaturated zone and saturated layers situated above the regional water table, whereby lower mountain ridges can be crossed. In this context it is interesting to mention some biotopes from where $\mathrm{Ni}$ phargus was recorded: in the Basque Country, for instance, in dripwater pools of a mine gallery, si-

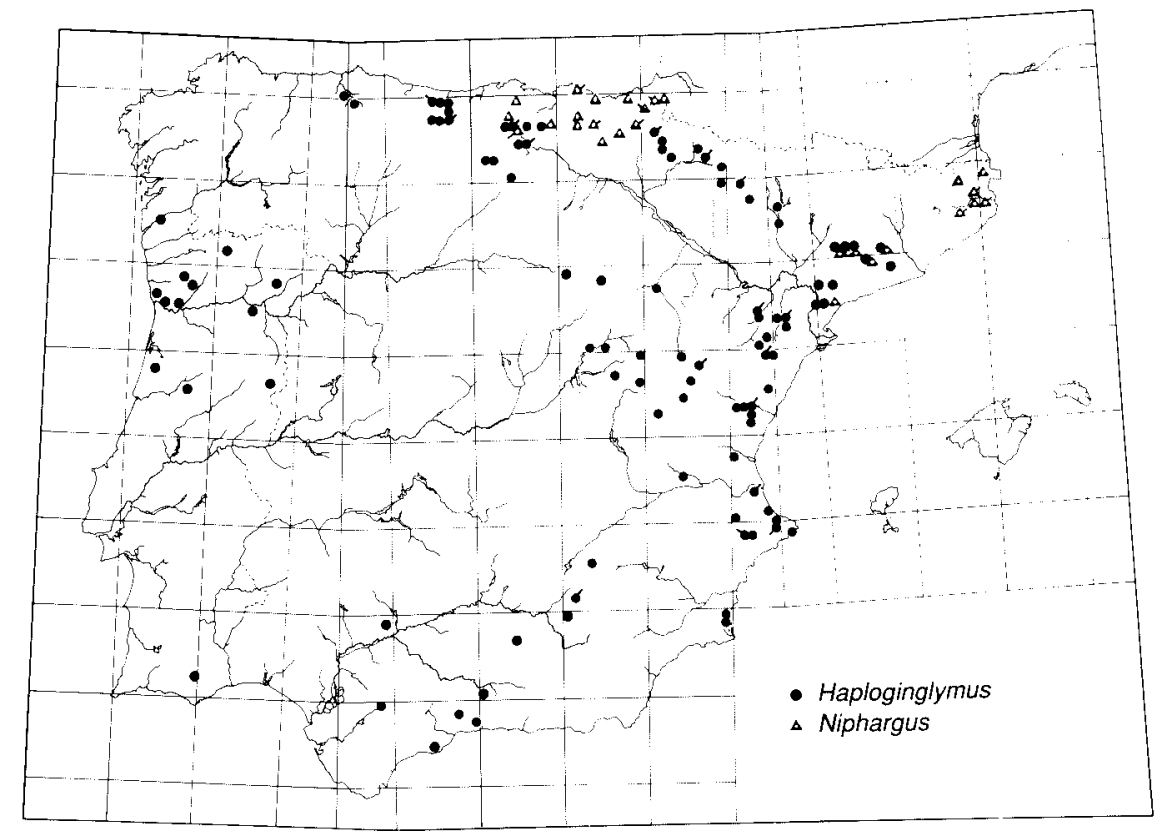

Figure 2.- The distribution of Haploginglymus and Niphargus in the Iberian peninsula. Squares indicate $100 \times 100 \mathrm{~km}$ UTM-gnd. Symbols with stack-bars indicate the situation of two or more localities of the genus within the same $10 \times 10 \mathrm{~km}$ UTM-square. Distribución de Haploginglymus y Niphargus en la península Ibérica. La cuadrícula corresponde a las coordenadas UTM de $100 \times 100$ $\mathrm{km}$. Los símbolos marcados con una línea indican la situación de dos o más localidades del género dentro del mismo cuadrado de coordenadas UTM de $10 \times 10 \mathrm{~km}$. 
tuated in non-carbonate rocks at $600 \mathrm{~m}$ altitude, without contact with the local groundwater table, and in a spring from red sandstone, situated high up a hill at $320 \mathrm{~m}$ altitude and with a $\mathrm{pH}$ of the water of 4.0. This spring is being fed most likely by a perched groundwater aquifer. In Catalonia most Niphargus records are from wells and hyporheic habitats, but it was found also in seeps of a railway tunnel.

In Basque Country Niphargus has been found in caves, springs, and wells, frequently together with Pseudoniphargus, very few times with Salentinella, and only once with Haploginglymus. In Catalonia the only amphipod co-occurring with Niphargus was Haploginglymus, in particular along the border of the range.

Haploginglymus Mateus \& Mateus, 1958 (fig. 2)

This genus, strictly endemic of the Iberian peninsula, is the most widely distributed Iberian stygobiont amphipod. It is uncertain if Haploginglymus occurs in the central part of Iberia, since few investigations have been done there. Until now four species are recognized (KARAMAN, 1986a; Pretus \& Sabater, in press), but since more material awaits identification, it is to be expected that more forms will be recognized.

The genus inhabits particular wells and underflows of rivers, but it has been found in springs as well. Only in the mid-eastern part of the peninsula are cave-dwellers recorded, possibly because of the absence of Pseudoniphargus in this region.

Haploginglymus is closey related to Niphargus (cf. Mateus \& Mateus, 1958; Barnard \& Bar NARD, 1983; KARAMAN, 1986a; KaRAMAN \& RuFFO, 1986). The observation that these two genera occur together only along the borders of their distribution areas would suggest that there is some kind competition between them. The genus is frequently found together with other amphipod genera.

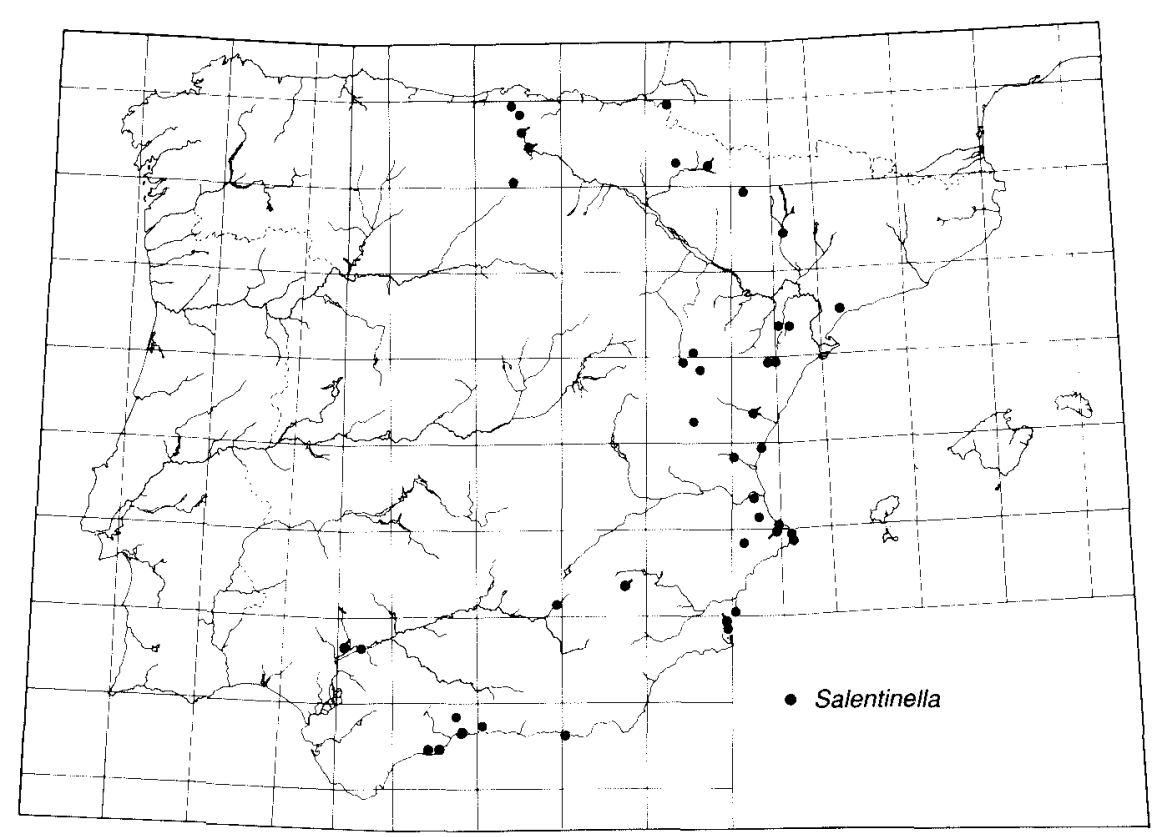

Figure 3.- The distribution of Salentinella in the Iberian peninsula. See also legend of fig. 2. Distribución de Salentinella en la península Ibérica. Véase también la leyenda de la figura 2 


\section{Salentinella Ruffo, 1947 (fig. 3)}

The genus is confined to fresh or sligthly brackish habitats of the western peri-Mediterranean region (Ruffo, 1986). In Spain Salentinella occurs in all regions prospected by us, not only close to the Mediterranean sea board, but also in inland ground waters and even in the vicinity of the Bay of Biscay. They are principally inhabitants of wells and underflows, although MARGALEF (1970a) recorded them also from a cave. Frequently Salentinella was found together with other stygobiont amphipods, especially with Haploginglymus.

Platvoet (1987) studied the Spanish material and recognized nine different forms, belonging to eight different (sub)species and one incertae sedis. The most widely distributed species is $\boldsymbol{S}$. angelieri, whose distribution coincides with that of the entire genus, and it occurs in various habitats near the Mediterranean coast, including insular habitats. In Spain it has been found up to some $100 \mathrm{~km}$ from the coast. The remaining Spanish species have restricted distributions often confined to a single hydrographic basin, including the uppermost parts of Atlantic drainage systems.

\section{Bogidiella Hertzog, 1933 (fig. 4)}

Species of Bogidiella were found in coastal ground waters, but also in continental ground waters. A part of the material available was studied by Stock \& Notenвoom (1988). They recognized five different species all endemic to Iberia belonging to the subgenera Bogidiella s.s. and Medigidiella. Cases of sympatry within Bogidiella, and between Bogidiella and Medigidiella are found in Iberian inland water (Sтоск \& NotenвоOм, op. cit.). In spite of intensive investigations, Bogidiella has not been found in the northern part of the central plateau (Meseta), the Cantabrian Mountains, the western Pyrenees, and inland waters of Catalonia.

Above all Bogidiella species are inhabitants of hyporheic habitats, although occasionally also

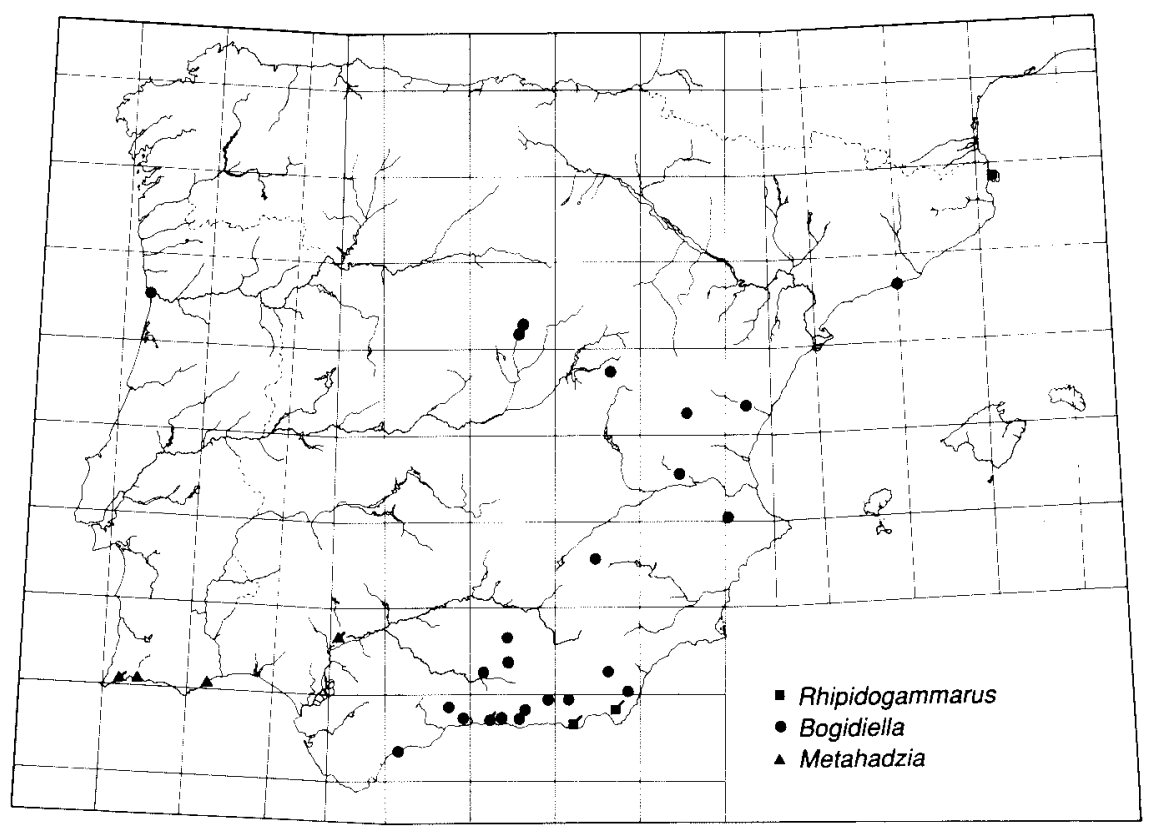

Figure 4.- The distnbution of Rhipidogammarus, Bogidiella and Metahadzia in the Iberian peninsula. See also legend of fig. 2. Distribución de Rhipidogammarus, Bogidiella y Metahadzia en la península Ibérica. Véase también la leyenda de la figura 2. 
found in wells. Frequently other stygobiont amphipods occured in the same habitats, viz., Pseudoniphargus, Haploginglymus, and Salentinella.

\section{Metahadzia Stock, 1977 (fig. 4)}

The genus Metahadzia has mainly a Mediterranean distribution. In the Iberian peninsula it was formerly known by a single species, $M$. tavaresi, from wells of the Algarve. Our own investigations revealed the existence of a second species, $M$. uncispina, in wells in the basin of the Quadalquivir river near Sevilla (Notenboom, 1988b). Probably the distribution in Spain of Metahadzia is limited to this river basin. The co-occurring amphipod fauna existed of Salentinella.

\section{Rhipidogammarus Stock, 1971 (fig. 4)}

A small number of localities with representatives of this genus are known from continental Spain, restricted to regions close to the Mediterranean sea board in fresh to brackish waters. Sтоск
(1971) mentioned R. rhipidiophorus from an epigean pool in a riverbed at Gerona. Our own investigations yielded a new species, R. triumvir, from wells in Almería (NotenBoom, 1985, 1988a).

\section{Sensonator Notenboom, 1986 (fig. 5)}

This monotypic endemic genus was discovered in the southern part of the province of Valencia. It is a rather large amphipod with remarkable characteristics for a stygobiont, such as many calceoli on both antennae in both sexes, and a subfoliaceous, natatory third uropod. The phylogenetic position of the genus is uncertain (NoTENBOOM, 1986a).

S. valentiensis was found in a phreatic cave lake (near Corbira de Alcira), but also in wells (near Corbera and Gandia) and in an hyporheic habitat of the Río Turia; all these localities are situated within $30 \mathrm{~km}$ from the sea shore in a rather restricted area. It has been found together with $\mathrm{Ha}$ ploginglymus, Salentinella, and Bogidiella. S. valentiensis is a bottom dweller but also free-swim-

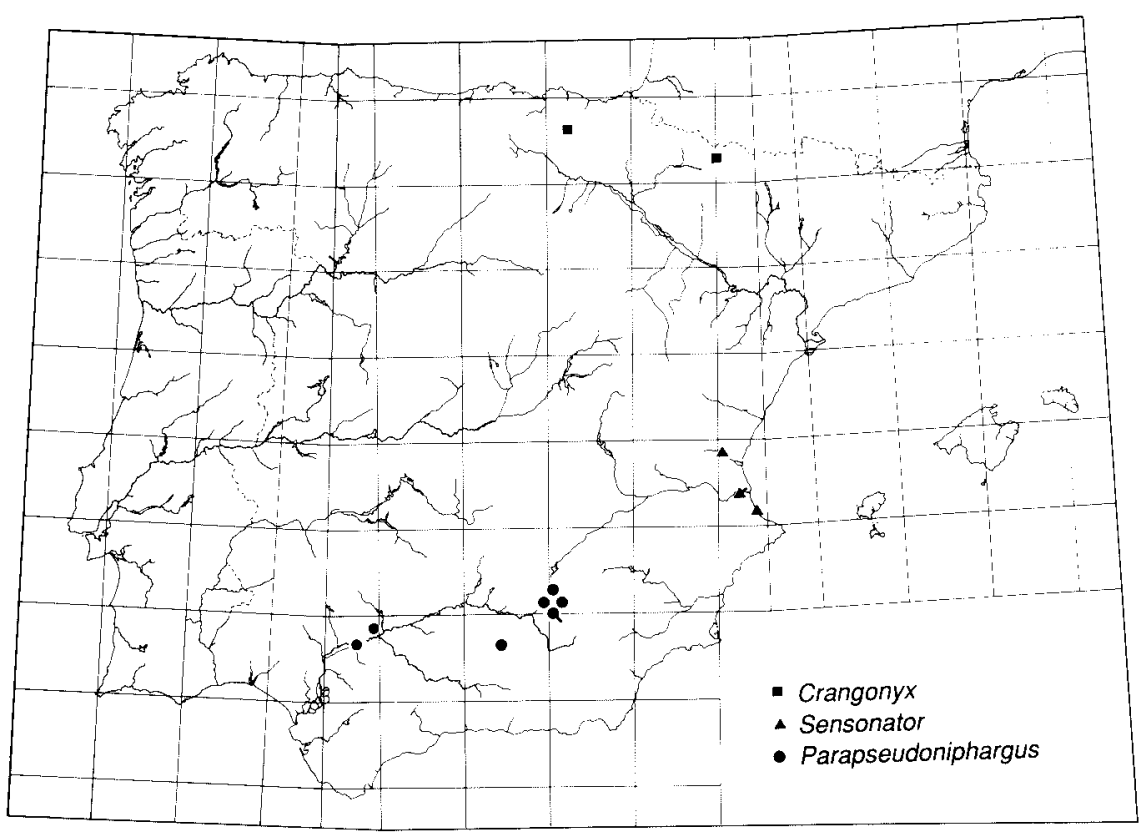

Figure 5.- The distnbution of Crangonyx, Sensonator and Parapseudoniphargus in the Ibenan peninsula. See also legend of fig. 2. Distribución de Crangonyx, Sensonator y Parapseudoniphargus en la península Ibérica. Véase también la leyenda de la figura 2. 
ming, and is supposed to be very sensitive to water-borne pressure waves, whether produced by animal vibrations or other disturbances in the water. Probably it is a predator which has its most favourable habitat in large waterfilled fissures of the saturated karst.

\section{Crangonyx Bate, 1859 (fig. 5)}

During our investigations species of this genus have not been discovered. Previously the genus was mentioned by Ginet (1977) from two caves in the north of Spain (Basque Country and Navarra). In spite of intensive sampling, also in one of the caves mentioned by Ginet (Cueva de Mairuelegoretta), it was not found again.

\section{Parapseudoniphargus Notenboom, 1988 (fig. 5)}

Our investigations revealed the existence of this monotypic genus closely related to Pseudoniphargus and probably endemic to the Guadalquivir river basin. The body of this amphipod is rather compact with deep coxal plates and relatively short posterior pereiopods and uropods, suggesting special adaptation to interstitial life (NoTENвоОм, 1988c). Parapseudoniphargus is distributed in hyporheic habitats of tributaries and upper courses of the Guadalquivir river, and occured together with Pseudoniphargus, Haploginglymus, and Salentinella.

Pseudoniphargus Chevreux, 1901 (fig. 6)

The genus has a western Mediterraneanamphi-Atlantic distributional range and the Iberian peninsula occupies a central position in it. In Iberia Pseudoniphargus has a disjunct distribution, with three ranges: northern Spain, southern Spain, and Lusitania. All these three ranges have their own assemblages of endemic species. Striking is the absence of Pseudoniphargus in the mideastern part of the peninsula. An ecological cause of this pattern seems unlikely because many other stygobiont crustaceans such as Haploginglymus, Salentinella, Proasellus, Stenasellus, and Ibero-

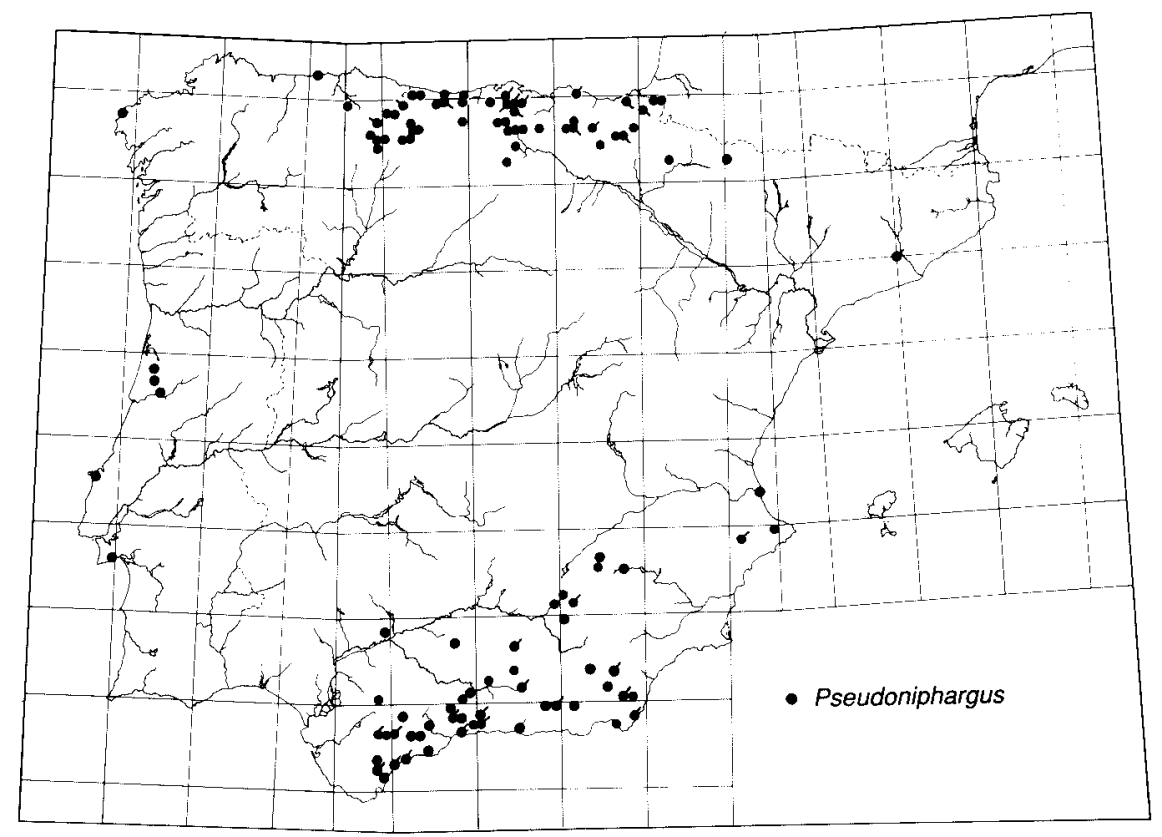

Figure 6.- The distnbution of Pseudoniphargus in the Ibenan peninsula. See also legend of fig. 2. Distribución de Pseudoniphargus en la península Ibérica. Véase también la leyenda de la figura 2. 
bathynella are abundant in this mid-eastern region, especially in hyporheic habitats, while Pseudoniphargus in the other areas investigated often co-occurred with these elements.

Karst waters provide important habitats for Pseudoniphargus in northern Spain, in addition, representatives are found in hyporheic waters, springs, and a few wells. Altogether 13 species have been recognized in the area, most of them with rather small allopatric ranges, limited to a single drainage basin or a karst area. In the Basque Country Pseudoniphargus frequently cooccurred with Niphargus. In hyporheic habitats, in particularly of the area around the Picos de Europa, Haploginglymus was often found together with Pseudoniphargus (NotenвoOm, 1986b). The presence of Pseudoniphargus in the Catalan hills (MARGAlef, 1970b) remains enigmatic, our own investigations in that area in 1986 did not reveal its presence.

Subterranean waters of southern Spain apparently support an important diversity of Pseudoniphargus species. In the 15 species recognized morphological divergence is larger than in northern Spain. Most of the southern species are allopatric with quite point shaped distributions. In the Guadalquivir basin, however, the widely distributed P. latipes co-occurred with the very localized species, $P$. illustris. Other amphipods frequently found together with Pseudoniphargus were Haploginglymus and Bogidiella, both mainly in hyporheic habitats, and Salentinella, only in wells (NoTENBOOM, 1987a).

Lusitania harbours a few species from Portugal and a single one from the northwesternmost part of Spain. The three species of Portugal are limited to the central-western part of the country (No. TENBOOM, 1987b).

\section{Zoogeographical districts}

Based on the known distributional data of stygobiont amphipods an attempt is made to divide to Iberian peninsula into areas characterized

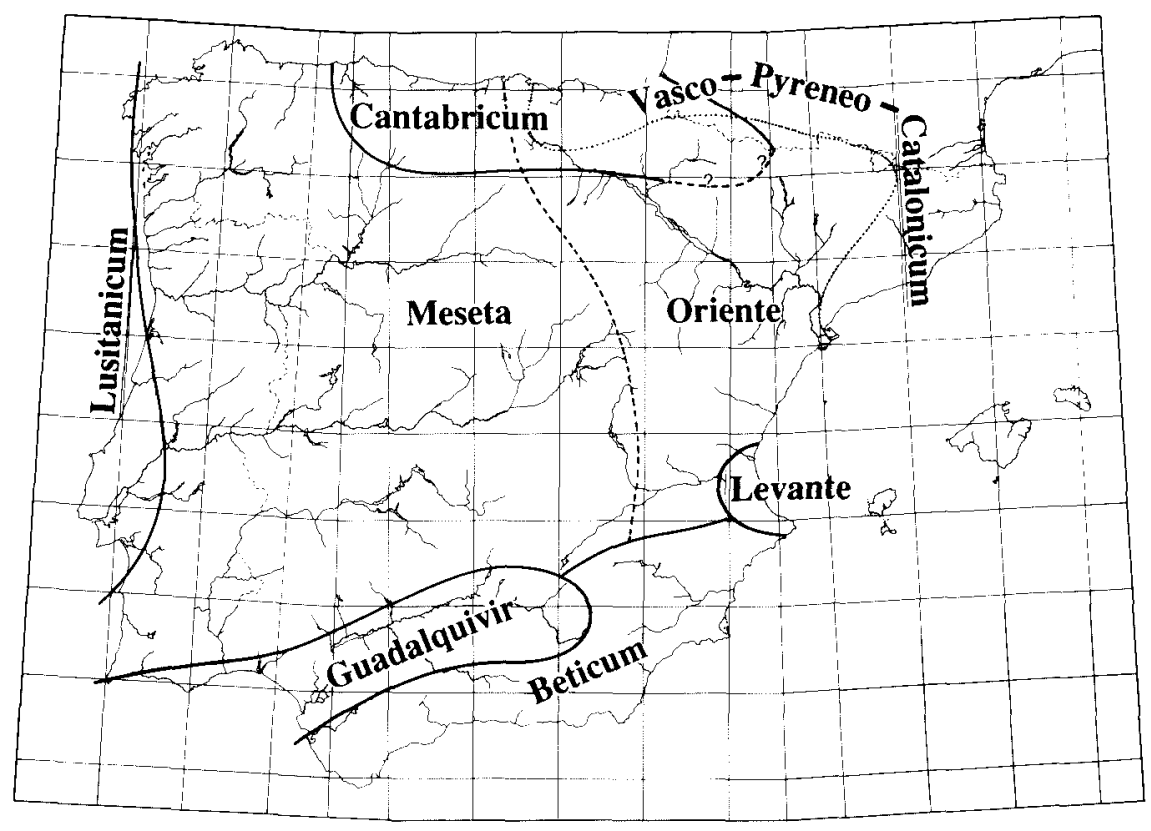

Figure 7.- Zoogeographic distncts of the Iberian peninsula based on presence or absence of stygobiont amphipods. Distritos zoogeográficos de la península Ibérica según la presencia o ausencia de anfípodos estigobiontes. 
by presence or absence of certain taxa. This approach is presented in fig. 7 , but it needs emphasize that not all Iberian regions are equally thoroughly investigated (see fig. 1).

The stygobiont amphipod districts tend to be situated at the periphery of the Iberian Meseta. The Meseta district apparently has the lowest diversity with Bogidiella and Haploginglymusonly. The latter genus is not particularly bound to any district, but an endemic for the entire peninsula. Regions with particular cases of endemism are the Guadalquivir and Levante with the endemic genera, $\mathrm{Pa}$ rapseudoniphargus and Sensonator, respectively. The unnamed taxon close to Salentinella, mentioned by PlatVoet (1987), might be an endemic of Levante, too. Moreover, the Guadalquivir district has endemic species of Pseudoniphargus and $\mathrm{Sa}$ lentinella, and is the only Iberian region with representatives of Metahadzia. Cantabricum, Lusitanicum, and Beticum are districts distinguished by the presence of various species of Pseudoniphargus, each with its own assemblage of endernic species. The eastern border of Cantabricum could not be established with certainty since it remains uncertain if Pseudoniphargus occurs in inland waters of the region southeast of the Pyrenees. The border between Oriente and Meseta is the western limit of the range of Salentinella. A VascoPyreneo-Catalonicum district is distinguished due to the penetration of Niphargus in Iberian ground waters. In northern Spain the ranges of the genera Pseudoniphargus, Niphargus and Salentinella are partially overlapping, the eastern zone of Cantabricum is inhabited by Salentinella, and the northern part of that zone by Niphargus.

In Iberia predominantly Mediterranean elements like Metahadzia and Salentinella are found in Atlan'tic drainage basins of Guadalquivir, Oriente and Cantabricum. The latter genus is recorded as well from the adjacent Aquitanian area

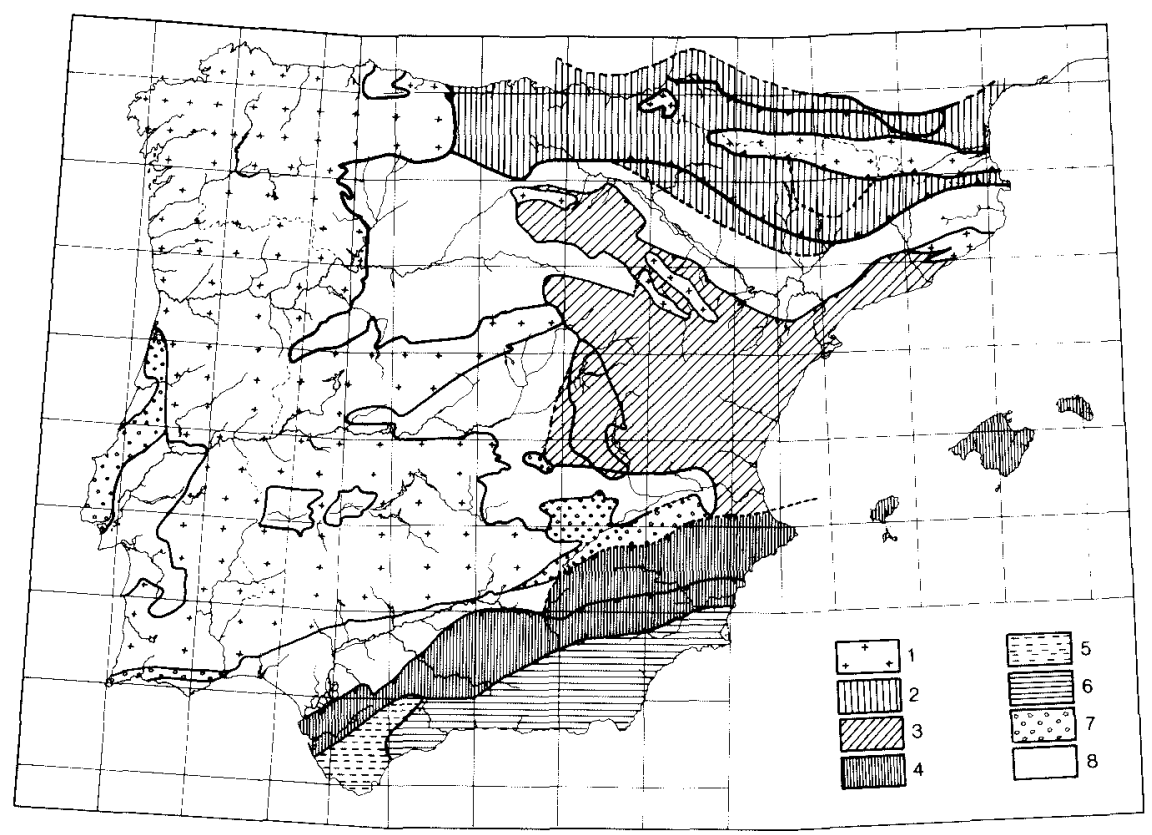

Figure 8.- Major geotectonic units of the Ibenan peninsula. 1) Hercynian basement; 2) deformed Mesozoid cover of the Pyrenean realm; 3) Mesozoic aulocogenic area; 4) Mesozoic external units of the Betic realm; 5) intermediate Flysch units of the Gibraltar arc; 6) internal units (Mesozoic and Paleozoic) of the Betic-Rif realm; 7) undeformed Mesozoic cover; 8) continental and marine. Principales unidades geotectónicas de la península Ibérica. 1) Zócalo hercínico; 2) cubierta mesozoica deformada del dominio pirenaico; 3) área ulocogénica mesozoica; 4) unidades mesozoicas externas del dominio bético; 5) unidades intermedias del Flysch del arco de Gibraltar; 6) unidades internas (Mosozoico y Paleozoico) del dominio Bético-Rif; 7) cubierta mesozoica indeformada; 8) continental y marino. 
in France. Another Mediterranean element is Rhipidogammarus which is restricted to coastal areas. Niphargus is a western paleartic element in Iberian ground waters. If the presence of Crangonyx could be confirmed this would be a holarctic element in the Iberian fauna. Pseudoniphargus, $\mathrm{Pa}$ rapseudoniphargus, and Metahadzia are hadzioid amphipods restricted to Tethyan areas. The Iberian range of Metahadzia apparently falls together with that of the thermosbaenacean Monodella with an amphi-Atlantic Tethyan distributional pattern as well. It is a remarkable fact that members of the Metacrangonyx group have not been found in Iberian ground waters; their presence in ground waters of the peninsula would be expected owing to their distribution in the Maghreb of North Africa and the Balearic islands.

\section{DISCUSSION}

The major geotectonic units of the Iberian peninsula are given in fig. 8. The Hercynian massif has remained uncovered by Mesozoic seas. Along the margins of this massif areas are situated which are strongly deformed during Alpine orogeny or which consist of Tertiary sedimentation basins. By comparing figs. 7 and 8 it is quite obvious that a certain correspondence exist between the amphipod districts and geological structures. The Hercy- nian massif roughly corresponds with the Meseta district and is poor in stygobiont amphipods. In contrast, the ranges of especially the hadzioid amphipods Pseudoniphargus, Parapseudoniphargus, and Metahadzia are limited to Mesozoic and Tertiary units. These genera are considered of direct marine origin and of low dispersal ability. These observations may indicate that the origin of hadzioid amphipods in continental ground waters demands mainly a vicariant explanation. The observation that the distribution of Pseudoniphargus and other hadzioid amphipods outside Iberia is limited to areas influenced by Late Cretaceous and Tertiary seas supports this idea. The distribution of the remaining genera shows no clear correlation with geotectonic units. In the explanation of the origin in Iberian ground waters of widespread genera, like Haploginglymus, Niphargus, Bogidiella, and Salentinella, apparently greater importance must be attached to dispersal and probably ecological determinism.

\section{ACKNOWLEDGEMENTS}

This paper is part of a $\mathrm{Ph}$. D. thesis project supported by the Foundation for Fundamental Biological Research (BION), which is subsidized by the Netherlands Organization for Scientific Research (NWO).

\section{RESUMEN}

\section{INTRODUCCIÓN AL ESTUDIO DE LOS ANFÍPODOS SUBTERRÁNEOS IBÉRICOS}

Se incluyen datos zoogeográficos de anfípodos de aguas subterráneas. Se discuten los rangos geográficos, los hábitats y la distribución de los géneros. La Península Ibérica se divide en distritos zoogeográficos basados en la distribución de los anfípodos, algunos de los cuales se correlacionan con unidades geológicas.

BIBLIOGRAPHY

Barnard, J.L. \& C.M. BARnard, 1983. Freshwater Amphipoda of the world 1 \& 2: 1-830. Hayfield Assoc., Mt. Vernon, Virginia.

CamaCho, A.I., 1987. La familia Parabathynellidae (Crustacea, Syncarida, Bathynellacea) en la península Ibérica: taxo- nomía, filogenia y biogeografia. Tesis doctoral, Universidad Autónoma de Madrid.

ESCOLÀ, O., 1980. Contribución al conocimiento de la fauna cavernícola del País Vasco. Kobie, Bilbao 10 (2): 539-541.

Ginet, R., 1977. Amphipodes troglobies d'Espagne. Crustaceana, suppl. 4: 173-176.

Ginet, R., 1980. Amphipodes troglobies d'Espagne. Exploracions 4: 27-32. 
Gomarin Guirado, F., 1978. Biospeleología de «La Cuevona». Cuadernos de Espeleología 3: 22. Santander.

HENRY, J.P. \& G. MaGNIEZ, 1987. Isopodes aselloides stygobies d'Espagne recoltes par J. Notenboom et I. Meijers. I Le genre Synasellus et description de trois nouvelles especes. Stygologia 3 (4): 331-344.

HENRY, J.P. \& G. MAGNIEZ, (1988). Isopodes asellö̈des stygobies d'Espagne récoltes par J. Notenboom et I. Meijers. II - Le genre Bragasellus et de description de sept nouvelles especes. Stygologia 4 (4).

KARAMAN, G.S., 1986a. Description of Haploginglymus mateusi, new species of subterranean Gammandea from Iberian peninsula with remarks to other taxa of this genus (Fam. Niphargidae). Poljoprivreda I Summarstvo 32 (1): 75-90.

KARAMAN, G.S., 1986b. Discovery of Niphargus delamarei Ruffo 1954 in Spain, with first descnption of females (Gammaridea: Niphargidae). Poljoprivreda I Summarstvo 33 (213): 29-42.

Karaman, G.S. \& S. RuFfo, 1986. Amphipoda: Niphargusgroup (Niphargidae sensu Bousfield, 1982). In: L. BotosANEANU (ed.), Stygofauna Mundi: 564-566, E. J. Brill, Leiden.

MARGALEF, R., 1952. La vida en las aguas dulces de los alrededores del Santuario de Nuestra Señora de Aránzazu (Guipúzcoa). Munibe 4: 73-108. San Sebastian.

MARGALEF, R., 1953. Los crustáceos de las aguas continentales Ibéricas. Biología de las aguas continentales, X: 1-243. Ministerio de Agricultura, Inst. Forestal de Inv. Exp. Madrid.

MARGALEF, R., 1970a. Anfípodos recolectados en aguas subterráneas ibéricas. Speleon 17: 63-65.

MARGALEF, R., 1970b. Anfípodos recolectados en aguas subterráneas del País Vasco. Munibe. 22 (314): 169-174. San Sebastián.

Mateus, A. \& M. De Lourdes Maciel, 1967. Descnption d'une nouvelle espèce de Bogidiella (Crustacea, Amphipoda) du psammon du Portugal et quelques notes sur son genre. Publ. Inst. «Dr. A. Nobre» (Fac. Ciencias Porto) 59: $1-15$.

Mateus, A. \& E. Mateus, 1958. Un nouveau genre et une nouvelle espèce d'Amphipode troglobie du Portugal . Publ. Inst. «Dr. A. Nobre» (Fac. Ciencias Porto) 59: 1-15.

Mateus, A. \& E. Mateus, 1972. Une nouvelle espèce d'Hadzia (Crustacea, Amphipoda) du Portugal. Publ. Inst. «Dr. A. Nobre» (Fac. Ciencias Porto) 117: 1-30.

Mateus, A. \& E. Mateus, 1978. Amphipoda hypogés du Portugal. Publ. Inst. «Dr. A. Nobre» (Fac. Ciencias Porto) 142: $1-26$.

NotenвOOM, J., 1985. Rhipidogammarus triumvir n. sp. (Amphipoda, Gammaridae) from wells near Mojonera, Almeria. Stygologia 1 (3): 292-299.

NotenвoOM, J., 1986a. Sensonator valentiensis n.g., n.sp. (Amphipoda), from different biotopes in southern Valencia. Bijdr. Dierk. 56 (1): 60-74.

Notenboom, J., 1986b. The species of the genus Pseudoniphargus Chevreux, 1901 (Amphipoda) from northern Spain. Bijdr. Dierk. 56 (1): 75-122.
Notenboom, J., 1987a. Species of the genus Pseudoniphargus Chevreux, 1901 (Amphipoda) from the Betic Cordillera of southern Spain. Bijdr. Dierk. 57 (1): 87-150.

NotenBoOM, J., 1987b. Lusitanian species of the amphipod Pseudoniphargus Chevreux, 1901 with a key to all Iberian species. Bijdr. Dierk. 57 (2): 191-206.

NotenBoOM, J., 1988a. Biogeographical observations on the genera of Iberian stygobiont Amphipoda. Crustaceana, Suppl. 13: 122-133

NotenBoOM, J., 1988b. Metahadzia uncispina, a new amphipod from phreatic groundwaters of the Guadalquivir nver basin of southern Spain. Bijdr. Dierk. 58 (1): 79-87.

NotenBoOM, J., 1988c. Parapseudoniphargus baetis, new genus, new species, a stygobiont amphipod crustacean from the Guadalquivir River Basin (southern Spain), with phylogenetic implications. J. Crust. Biol. 8 (1): 110-121.

NotenboOM, J. \& I. MeIJERS, 1985. Investigaciones sobre la fauna de las aguas subterráneas de España: lista de estaciones y primeros resultados. Versl. techn. Gegevem (Inst. taxon. zool., Univ. Amsterdam) 42: 1-93.

ORTIZ, E., 1968. Algunos crustáceos y miriápodos cavernícolas. Cuadernos de Espeleología 3: 85-87. Santander.

Pesce, G.L. \& D. Galassi (in press). Groundwater crustaceans of Spain 11: Microparasellidae of Spain. Stygologia 4 (4)

Platvoet, D., 1987. The genus Salentinella Ruffo, 1947 (Crustacea, Amphipoda) in Spain. Stygologia 3 (3): 217-240.

RuFfo, S., 1953. Anfipodi di acque interstiziali raccolti dal Dr C. Delamare Debouteville in Francia, Spagna e Algena. Vie et Milieu 4 (4): 669-681.

RUFFO, S., 1986. Amphipoda: Salentinellidae. In: L. BotosA. NEANU (ed.), Stygofauna Mundi: 564-566. E. J. Brill, Leiden.

STOCK, J.H., 1971. A revision of the Sarathrogammarus-group (Crustacea, Amphipoda). Bijdr. Dierk. 41 (2): 94-129.

STOCK, J.H., 1977. The taxonomy and zoogeography of the hadziid Amphipoda. Stud. Fauna Curaçao 55: 1-130.

Sтоск, J.H., 1980a. Découverte, dans le nord-ouest de l'Espagne, d'une deuxième espèce d'Haploginglymus, genre de Crustacés Amphipodes endémiques de la Peninsule Ibérique. Bull. zool. Mus. Univ. Amsterdam 7 (14): 141-147.

StOCK, J.H., 1980b. Regression model evolution as exemplified by the genus Pseudoniphargus (Amphipoda). Bijdr. Dierk. 50 (1): 105-144.

Sтоск, J.H., 1986b. Amphipoda: Gammarid grouping (Gammaridae s. str. sensu Bousfield) In: L. BOTOSANEANU (ed.), Stygofauna Mundi: 504-513. E. J. Bnll, Leiden.

STOCK, J.H., 1986c. Amphipoda: Melitid grouping (Melitidae sensu Bousfield, 1973, emend.). In: L. BotosanEANu (ed.), Stygofauna Mundi: 504-513. E. J. Brill, Leiden.

Stock, J.H. \& J. NotenвoOM, 1988. Five new bogidiellid Amphipoda from Spain - the first freshwater records in the Iberian Peninsula. Hydrobiologia 164: 75-95.

VEgAS, R. \& E. BANDA, 1982. Tectonic framework and Alpine evolution of the Iberian peninsula. Earth Evolution Sciences 4: 320-343.

Villota, J. \& C. Galan, 1970. Complejo Lerzo-Anudia IISabe Saia-Ko-Lezia. Munibe 22 (314): 175-182. San Sebastián. 